ks. Sławomir Bukalski

ORCID: 0000-0002-9768-4634

Uniwersytet Szczeciński

\title{
Posługa myślenia wobec współczesnego stanowiska Ecclesia turpis. Refleksja teologiczno-psychologiczna
}

Od dwóch tysięcy lat Kościół doświadcza z jednej strony chwały, blasku, szczególnego splendoru, a z drugiej strony pogardy, hańby, wstydu. Można by rzec, że to oczywisty proces, skoro Kościół tworzą zarówno święci, jak i grzesznicy. Te antonimy w różnych okresach historii nabierały szczególnej siły i niosły ze sobą wzrost znaczenia Kościoła w świecie lub przeciwnie - jego marginalizację. Historia pokazuje, że w każdym stuleciu walka z Kościołem przybierała różną formę i różną skalę. W czasach współczesnych chrześcijanie są najbardziej prześladowaną grupą w świecie. Źródłami ich prześladowania są aktualnie ekstremizm islamski, fanatyzm hinduistyczny bądź buddyjski, komunizm oraz ateistyczna kultura śmierci . Zorganizowanym wrogom Kościoła trudno jest go pokonać metodą merytorycznych argumentów, więc najprostszy mechanizm sprowadza się do wcześniejszego zohydzenia Kościoła i chrześcijan, po czym następują prześladowania. Zwykle jest to proces polegający na tym, aby z tego, co jest patologicznym wyjątkiem, uczynić - za pomocą medialnej manipulacji i kampanii propagandowej - zasadę i powszechne uogólnienie. Natomiast z tego, co jest regułą i celem chrześcijańskiego życia, np. ze świętości

1 Por. Radio Watykańskie, Doroczny raport usa o wolności religijnej w świecie, http://pl.radiovaticana.va/news/2017/08/17/doroczny_raport_usa_o_wolno\%C5\%9Bci_religijnej_w_\%C5\%9Bwiecie/1331272 (5.08.2018). 
i prawości życia, zrobić sytuacje wyjątkowe. W ten sposób wrogowie Kościoła tworzą ohydny obraz Kościoła - Ecclesia turpis.

W tym kontekście aktualne staje się pytanie: czy można bronić się przeciw strategii zohydzania Kościoła? Poniższe spojrzenie i próba szukania odpowiedzi jest refleksją teologiczno-psychologiczną. Punktem wyjścia jest analiza pojęcia „posługa myślenia” według Jana Pawła II i zagrożenie wynikające z odrzucenia tej posługi. Kolejny etap to ukazanie współczesnych mechanizmów zohydzania Kościoła. Na końcu zostanie zaproponowane stanowisko wobec powyższego procesu².

\section{Posługa myślenia}

Święty Jan Paweł II w 1997 roku w Krakowie wypowiedział bardzo znamienne słowa dotyczące „posługi myślenia”. Choć słowa te wypowiedziane w murach Uniwersytetu Jagiellońskiego skierowane były przede wszystkim do ludzi nauki, to z całą pewnością są one aktualne także w stosunku do każdego wyznawcy Chrystusa. „Niewiele jest rzeczy równie ważnych w życiu człowieka i społeczeństwa, jak posługa myślenia. «Posługa myślenia», o której mówię, to w swej istocie nic innego jak służba prawdzie w wymiarze społecznym [...]. Nie wystarcza bowiem troska o logiczną, formalną poprawność procesu myślenia. Czynności umysłu muszą być koniecznie włączone w duchowy klimat niezbędnych cnót moralnych, jak szczerość, odwaga, pokora, uczciwość oraz autentyczna troska o człowieka. Dzięki wrażliwości moralnej zachowana zostaje bardzo istotna dla nauki więź pomiędzy prawdą a dobrem. Tych dwóch spraw nie można bowiem od siebie oddzielać!"3.

W świetle powyższego „posługa myślenia” to przede wszystkim szukanie prawdy i dobra w życiu osobistym oraz w życiu społecznym. Punktem wyjścia w zrozumieniu „posługi myślenia” jest personalistyczna koncepcja osoby wskazująca na specyficzne atrybuty człowieczeństwa - rozumność, wolność, odpowiedzialność, zdolność do realizowania wyższych wartości, świadomość, samostanowienie, a najbardziej właściwą relacją do każdej osoby jest relacja miłości. W kontekście personalizmu chrześcijańskiego należy dostrzegać

${ }^{2}$ Niniejszy artykuł nie jest wyrazem oficjalnego stanowiska Kościoła. Jest raczej głosem $\mathrm{w}$ dyskusji.

3 Jan Paweł II, Przemówienie wygłoszone z okazji sześćsetlecia Wydziału Teologicznego Uniwersytetu Jagiellońskiego, Kraków 8 czerwca 1997, https://ekai.pl/dokumenty/przemowieniewygloszone-z-okazji-szescsetlecia-wydzialu-teologicznego-uj/ (15.09.2018). 
służbę prawdzie w wymiarze społecznym. Prawda i mądrość, do których Jan Paweł nawiązał w dalszej części swojej wypowiedzi dotyczącej „posługi myślenia”, ma z kolei mocne uzasadnienie w fenomenologicznej szkole myślenia, która ukształtowała intelektualny profil nauczania Jana Pawła $\mathrm{II}^{4}$. Nieumiejętność odróżnienia prawdy od kłamstwa i dobra od zła zwykle uniemożliwia realizowanie zarówno prawdy, jak i dobra.

Kontekst papieskiej nauki o posłudze myślenia uwzględnia także rzetelne dociekanie prawdy i przekazywanie wiedzy. Ta czynność jest niezmiernie ważna zarówno w wymiarze społecznym (dla Kościoła, narodu, państwa, każdej wspólnoty), jak również w wymiarze indywidualnym. Chodzi bowiem o orientację w otaczającym świecie. Subiektywna prawda człowieka bardzo często odbiega od obiektywnej prawdy o człowieku. W czasach subiektywizacji prawdy, nieufności do odkrywania prawdy ludzkim rozumem oraz w utożsamiania wolności z samowolą Jan Paweł II, a wcześniej kardynał Karol Wojtyła bardzo mocno ukazywał postawę ufności w ludzki rozum. Rzetelne przekazywanie wiedzy musi być powiązane przede wszystkim z nawiązywaniem do faktów i merytorycznych analiz oraz badań - także tych empirycznych, istotnych statystycznie. Wiedza - również ta dotycząca nadużyć seksualnych - nie może być gromadzona na zasadzie mechanicznej akumulacji. Ona musi mieć przede wszystkim mocny wymiar humanistyczny5.

Wskazując na społeczną przestrzeń posługi myślenia, należy zauważyć, że z chrześcijańskiej koncepcji osoby oraz obowiązku troski o dobro wspólne wynika obowiązek odkrywania prawdy oraz wskazywania dobra, a także prawo do oceny moralnej różnych działań społecznych. Ta ocena moralna nie jest oczywiście czymś „na eksport” - do wykorzystania przez osoby spoza Kościoła, ale przede wszystkim powinna dotyczyć własnych zachowań. Tu ujawnia się proces kształtowania ludzkich sumień. Kościół może skutecznie realizować ten proces, gdy czynności umysłu są realizowane w klimacie cnót moralnych. $\mathrm{Na}$ ten aspekt chrześcijańskiego życia Jan Paweł II zwracał uwage polskim biskupom w 1998 roku, czyli niecały rok po słynnych słowach wypowiedzianych w murach Uniwersytetu Jagiellońskiego dotyczących posługi myślenia. Papież przywołał wówczas swoją wypowiedź sprzed roku. „Ludzie nauki, środowiska naukowe, uniwersyteckie, ludzie pióra i twórcy kultury, doświadczając swoistej

${ }_{4}$ Por. E. Wolicka, Postuga myślenia - Jana Pawła II idea uniwersytetu, w: Fenomen uniwersytetu, red. A. Grzegorczyk, J. Sójka, Poznań 20o8, s. 76; por. także K. Wojtyła, Miłość i odpowiedzialność, Lublin 2001, s. 14 .

5 Por. E. Wolicka, Posługa myślenia..., dz. cyt., s. 77. 
transcendencji prawdy, piękna i dobra, stają się naturalnymi sługami tajemnicy Boga [...], «bez względu na przekonania, są powołani do tego, by pełnić funkcję sumienia krytycznego wobec tego wszystkiego, co człowieczeństwu zagraża lub go pomniejsza». W ten sposób «posługa myślenia», której można oczekiwać od ludzi nauki i kultury, spotyka się z posługą, jaką wobec sumień ludzkich pełni Kościół”'.

\section{Konsekwencje marginalizacji \\ oraz eliminowania "posługi myślenia”}

Marginalizacja lub eliminowanie tej ważnej posługi z życia chrześcijanina to najprostsza droga do kształtowania swoistej mentalności niewolnika u człowieka, nad którym zamierza się sprawować kontrolę. Człowiek może oczywiście sam w swoich wyborach zwolnić się z odpowiedzialności i zagubić „posługę myślenia” oraz zatracić ją w życiu społecznym. Może to się dziać na drodze własnej błędnej aktywności. Ale bywają oddziaływania zamierzone - oddziaływania manipulacyjno-propagandowe, które mają na celu oderwanie człowieka od prawdy i dobra. Znany psycholog z nurtu psychologii humanistycznej Abraham Maslow stwierdza w jednym ze swoich dzieł: „zbyt wielu ludzi nie decyduje o sobie, lecz pozwala za siebie podejmować decyzje [...]. Ludzie ci są pionkami poruszanymi przez innych, a nie jednostkami samodzielnie działającymi, samookreślającymi się"7. Słowa te odnoszone są do wymuszenia zachowań mających na celu podjęcie konkretnych decyzji $\mathrm{z}$ przekonaniem, że te decyzje to wyraz własnej woli i własnego rozumu. Ten mechanizm jest uznawany za najwyższy poziom manipulacyjny ${ }^{8}$. Przykładem tego mechanizmu mogą być sytuacje, gdy ludzie Kościoła, występując przeciw Kościołowi są przekonani, że podejmują działania, które są owocem ich własnego przemyślenia. Tymczasem zazwyczaj realizują cele wrogów Kościoła.

6 Jan Paweł II, Odnowa człowieka i społeczeństwa dokonuje się za sprawa odnowy sumień. Przemówienie Ojca Świętego do III grupy biskupów polskich z wizytą ad limina, Rzym 14.02.1998, „L'Osservatore Romano” (wyd. pol.) $1998 \mathrm{nr}$ 3, s. 44; por. także D. Żukowska-Gardzińska, Kulturowe wyposażenie osoby, „Fides et Ratio” 24 (2015) nr 4, s. 65.

A. H. Maslow, Motywacja i osobowość, przeł. P. Sawicka, Warszawa 1990, s. 227.

8 Por. R. Cialdini, Wywieranie wpływu na ludzi. Teoria i praktyka, przeł. B. Wojciszke, Gdańsk 1996, s. 51-60; także S. Bukalski, Manipulacyjny język w grupach kultowych, w: Język przekazu religijnego, red. D. Krok, S. Pawiński, Opole 2006, s. 65-79; T. Witkowski, Psychomanipulacje, Wrocław 200o, s. 82-91. 
Modelowanie mentalności niewolnika dokonywane jest na szeroką skalę poprzez szczególny rodzaj manipulacji społecznej - przez tzw. inżynierię społeczną („,behawiorystyczna metoda modyfikacji człowieka”). Współczesny polski psycholog Józef Kozielecki opisał takie praktyki w naszej ojczyźnie w czasach socjalizmu. Lewicowa inżynieria społeczna w tamtych czasach była jednak nieudolna i niedoskonała. Dziś, liberalno-lewicowa inżynieria społeczna realizuje te same cele, co w systemie totalitarnym, czyli zmierza do władzy i kontroli nad społeczeństwem, w tym także władzę nad Kościołem. Techniki manipulacji są oczywiście o wiele doskonalsze niż kilkadziesiąt lat temu. Współczesna inżynieria społeczna wykorzystuje cały szereg technik w stosunku do Kościoła: ośmieszanie; podpieranie się tzw. autorytetami (często są to zadeklarowani ateiści lub księża, którzy porzucili kapłaństwo); selekcja faktów; pomówienia mające poniżyć i odebrać wiarygodność pomawianego; przypinanie etykiet: np. wroga, homofoba, oszołoma, zacofanego, działającego przeciw kobietom, kogoś z zaścianka; łączenie kłamstw z prawdami. Powszechnym sposobem manipulacji jest posługiwanie się fikcyjnymi wynikami z sondaży. W relacji do Kościoła stosunkowo często nie mają one związku z rzeczywistością. Chodzi o to, aby odbiorca wiadomości nabywał przekonanie, że jest to zdanie większości, i że w tej jedynie słusznej grupie trzeba się znaleźć.

Inżynieria społeczna stawia sobie za cel stworzenie tzw. człowieka zewnątrzsterownego. W czasach socjalizmu próbowano skonstruować człowieka kolektywnego, produktywnego, uległego władzy, ateistę. Ten eksperyment jednak się nie powiódł. Ówczesnym propagandzistom nie udało się wyplenić najszlachetniejszych cech Polaków, np. wiary w Boga i związku z Kościołem9. We współczesnej inżynierii społecznej szczególny wysiłek propagandy zmierza więc do tego, aby zmieniać myślenie Polaków poprzez wcześniejsze niszczenie wiary w Boga. Ostrze współczesnej inżynierii behawioralnej skierowane jest bezpardonowo w instytucję Kościoła i ludzi wierzących. Bardzo trafnie tę współczesną rzeczywistość w Polsce ocenił kard. Gerhard Müller: „dzisiejszy atak na Polskę jest gorszy, bo wtedy [w okresie rozbiorów - dopisek własny] rozerwano tylko ciało. Dzisiaj chodzi o śmiertelny cios, który ma być zadany polskiej duszy"10.

9 Por. J. Kozielecki, Koncepcje psychologiczne człowieka, Warszawa 1996, s. 92-93.

10 Wypowiedź podczas II Międzynarodowego Kongresu Europa Christi w dniu 18 października 2018 roku: G. Müller, Żaden kraj nie ma prawa pouczać Polski na temat demokracji, https://www. gosc.pl/doc/5099501.Kard-Mueller-Zaden-kraj-nie-ma-prawa-pouczac-Polski-na-temat (18.10.2018). 
Problem mentalności niewolnika od strony teologicznej podejmuje Jacek Salij. „Niewolnik to taki człowiek, który swój rozum i wolę ma poza sobą. Albo jeszcze inaczej: podatność na manipulację jest podstawową cechą mentalności niewolniczej"11. Autor nawiązuje tu wprost do dzieła Arystotelesa Etyka nikomachejska. Podejmuje także temat mentalności niewolnika, gdy przywołuje Cypriana Kamila Norwida i postawy, jakie poeta widział w Polakach. Salij w tym kontekście sporządza listę cech wspomnianej mentalności: zuchwalstwo i naśladownictwo, zdumiewający brak zainteresowania dla prawdy, asymetria między myślą i czynem, brak szacunku dla siebie samego oraz nienawiśćc ${ }^{12}$. „Każdy bowiem, kto popełnia grzech, jest niewolnikiem grzechu” (J 8, 34). Człowiek o mentalności niewolnika to ten, który popełnia grzech i w tym grzechu żyje, to człowiek z zagłuszonym sumieniem. Osoby dopuszczające się nadużyć seksualnych wobec nieletnich, czyli angażując się w szczególnie ohydny rodzaj grzechów, wykazują się skrajnie nasiloną mentalnością niewolnika. Niewolnik jest niezdolny do wyrażenia swojej oceny rzeczywistości i rozeznania prawdy i dobra, jest niezdolny do podjęcia samodzielnych wyborów. Inni nim kierują i za niego decydują. To podejście teologii jest bardzo zbieżne z tym, co mówi psychologia.

Mentalność niewolnika ujawnia się także w ignorancji dotyczącej faktycznej wiedzy na temat nadużyć seksualnych wśród duchownych i jednoczesnego formułowania radykalnych wniosków w powyższej kwestii. Ta mentalność ujawnia się zarówno po stronie Kościoła, jak i po stronie antykościelnej propagandy. W tej drugiej grupie przybiera ona aktualnie wręcz monstrualne rozmiary.

\section{Proces zohydzania Kościoła - Ecclesia turpis}

Proces zohydzania Kościoła i niszczenia autorytetu jest współcześnie mocno związany z oczernianiem, wyszydzaniem, dyskredytowaniem, krytykanctwem, uogólnianiem i rozdmuchiwaniem słabości oraz podnoszeniem ich do niebotycznych rozmiarów. Medialna manipulacja i antykościelna propaganda żąda wręcz, aby Kościół zmienił pochodzące od Boga prawdy wiary i moralności, naukę dotyczącą małżeństwa i rodziny, związków jednopłciowych, aborcji, antykoncepcji. Propagandziści dobrze wiedzą, że chrześcijanin

${ }^{11}$ J. Salij, Dwa opisy mentalności niewolniczej, „Arcana” $1997 \mathrm{nr}$ 15, s. 142.

${ }_{12}$ Zob. J. Salij, Ośrodek Myśli Politycznej, Mentalność niewolnicza jako problem narodowy, http://www.omp.org.pl/artykul.php?artykul=167 (5.10.2018). 
ze swoją „posługą myślenia” stanowi największą przeszkodę dla inżynierii społecznej. Stąd ogromny wysiłek, aby ośmieszać osoby duchowne i świeckie, aby podważać autorytet duszpasterzy, dyskredytować katolików świeckich, aby ukazywać ludzi Kościoła jako osoby szczególnie niewiarygodne. Szerzone jest przekonanie, że Kościół co najwyżej może być instytucją charytatywną, ale nie powinien wskazywać współczesnemu człowiekowi norm moralnych, które prowadzą tegoż człowieka do prawdy i dobra, a w konsekwencji do świętości.

Różne sposoby i metody zohydzania Kościoła sprowadzają się tak naprawdę do mechanizmu znanego $\mathrm{z}$ historii - mechanizmu obrzucania błotem. Arthur Schopenhauer ukazał dokładnie sposoby dominacji nad rozmówcą, w których osoby będące w sporze, nie zważając na prawdę i logikę, narzucają swoje zdanie w taki sposób, aby zmusić rozmówcę do przyjęcia własnych argumentacji i racji1 ${ }^{13}$. Historycy badający sposoby werbunku i zachowania księży-agentów w czasach PRL-u wskazują na podstawową metodę sprowadzającą się do realizacji hasła: „worek, korek i rozporek”. Te trzy najpopularniejsze zarzuty stawiane osobom duchownym dotyczyły pazerności finansowej, nadużywania alkoholu, łamania wstrzemięźliwości seksualnej oraz wywoływania skandali obyczajowych $^{14}$. Dziś na te same obszary wskazują przeciwnicy Kościoła, bazując na odrażających przypadkach, które są w zdecydowanej mniejszości, i czynią z nich zasadę funkcjonowania Kościoła.

Antychrześcijańska propaganda ma swój początek już w starożytności. Znana jest choćby inwektywa Marka Frontona, który nie znając nauki chrześcijańskiej, zarzucał chrześcijanom m.in. uprawianie kazirodztwa, czczenie oślej głowy czy też rytualne mordy ${ }^{15}$. Inny przykład to graffiti Aleksamenosa przedstawiające ukrzyżowanego człowieka z głową osła pochodzące z I-III wieku. W czasach reformacji antykatolicka ikonografia, karykatury biskupów, kardynałów i samego papieża, które porównywały wizerunki hierarchów Kościoła do odrażających zwierząt, były wykorzystywane ze zdwojoną siłą. Ten zabieg animalizacji i dehumanizacji miał na celu zohydzenie osób oraz instytucji. Kontynuacja tego procesu miała miejsce w czasach rewolucji francuskiej, zaborów oraz obu systemów totalitarnych. W czasach nam współczesnych proceder

${ }^{13}$ Zob. A. Schopenhauer, Erystyka, czyli sztuka prowadzenia sporów, tłum. Ł. Konorska, B. Konorski, Warszawa 2012.

${ }_{14}$ Zob. A. Ivanowitz, Korek, worek i rozporek, http://www.pospoliteruszenie.org (2.10.2018); zob. także P. Gursztyn, Korek, worek i rozporek, http://wiadomosci.dziennik.pl/opinie/artykuly/14816o,korekworek-i-rozporek.html (2.10.2018).

${ }_{15}$ Por. M. Starowieyski, Pierwsi świadkowie. Pisma Ojców Apostolskich, Kraków 2010, s. 378-385. 
wywoływania u odbiorcy najohydniejszych skojarzeń wobec Kościoła ciągle jest kontynuowany. Dokonuje się on dziś poprzez obraz w sztuce i filmie. Pod szyldem fałszywie pojętej tolerancji dochodzi do publicznego wyszydzania i oczerniania Kościoła.

Przedstawienia oraz filmy mają na celu wywołać u widza negatywne emocje w stosunku do Kościoła. Ta emocjonalna stygmatyzacja (etykietowanie, napiętnowanie) dokonuje się zwykle bez weryfikacji rzeczywistości. „Napiętnowanie prowadzi do społecznego odrzucenia jednostek $z$ uwagi na posiadane przez nie jakiejś cechy, która dyskwalifikuje je jako ludzi w oczach innych"16. W kontekście analizowanego mechanizmu stygmatyzacja polega na nadawaniu Kościołowi lub jego przedstawicielom zdecydowanie negatywnych cech, czynieniu z osób duchownych przestępców, którzy nie są równi wobec prawa, ukazywaniu duchownych jako ludzi łamiących nauczanie Kościoła oraz nieprzestrzegających przepisów prawa, a mimo to nauczających innych ludzi zachowań moralnych. Stygmatyzacja polega także na ukazywaniu biskupów jako tych, którzy ukrywają kryminalne zachowania duchownych.

Wydaje się, że apogeum zohydzania Kościoła i dehumanizacji jego przedstawicieli miało miejsce w czasach niemieckiego nazizmu. Przyjęto jednak nową strategię. Otóż to Joseph Goebbels opracował metodę najmocniejszego uderzenia w wizerunek Kościoła poprzez zarzucanie wszystkim duchownym nadużyć seksualnych, zwłaszcza wobec nieletnich. To z polecenia tego propagandzisty „pomiędzy 1934 a 1937 rokiem w nazistowskich Niemczech toczono publiczne procesy przeciwko kapłanom i zakonnikom katolickim oskarżonym o występki przeciwko moralności, w wyniku czego jedynie 64 na 2500 obciążonych zarzutami udało się udowodnić winę"17.

Fala ataku i zohydzania Kościoła polega dziś na mówieniu o powszechnych nadużyciach seksualnych duchownych w oparciu o stosunkowo nieliczne przypadki udokumentowanej i skazanej sądownie pedofilii. Liczba przypadków nie jest oczywiście usprawiedliwieniem i już w tym miejscu musi być wyrażone

${ }^{16}$ J. Crocker, Piętno, stygmat, w: A. Manstead, M. Hewstone, Encyklopedia Blackwella. Psychologia społeczna, red. naukowa J. Czapiński, tłum. zbior., Warszawa 1996, s. 348; zob. także N. Emler, Etykietowanie, w: A. Manstead, M. Hewstone, Encyklopedia Blackwella..., dz. cyt., s. 104; M. Kamińska-Feldman, Wokół problemu dehumanizacji innych: próba uchwycenia zjawiska stygmatyzacji, w: Poza egocentryczna perspektywa widzenia siebie i świata, red. M. Jarymowicz, Warszawa 1994, s. 63-86.

${ }_{17}$ R. Skrzypczak, Chrześcijanin na rozdrożu, Kraków 2011, s. 190, za: G. Mosse, Sessaualitá e nazionalismo. Mentalitá borghese e rispettabilitá, Roma 1996; zob. także G. Kucharczyk, Antykatolickie kampanie, „Nasz Dziennik” 22-23.09.2018, s. 8. 
jasne stanowisko: choćby jeden przypadek nadużyć seksualnych wobec nieletnich w Kościele (pedofilia ${ }^{18}$ lub efebofilia ${ }^{19}$ ) jest sytuacją niedopuszczalną, jest o jeden przypadek za dużo! Ale należy przyjrzeć się statystykom, aby mieć jasny obraz analizowanego problemu. Dotychczas najbardziej obszerne i wiarygodne badania wskazanego problemu zostały przeprowadzone w Stanach Zjednoczonych. Dwa kolejne raporty: australijski oraz niemiecki powinny także stanowić materiał do merytorycznej refleksji.

Pierwszy raport ukazuje badania pod kątem nadużyć seksualnych wśród wszystkich księży katolickich pracujących w USA w latach 1950-2002 (okres 52 lat). Dokonała tego bardzo renomowana, niezależna od Kościoła uczelnia kryminologiczna John Jay College of Criminal Justice. Przeanalizowano życiorysy ponad blisko 110 tysięcy kapłanów i niemalże wszystkie instytucje kościelne. W 2004 roku opublikowano raport, z którego wynikało, że ponad 90\% księży katolickich skazanych w us A za wykorzystywanie seksualne dzieci to homoseksualiści, a $81 \%$ ofiar stanowili chłopcy. W raporcie wskazano 4392 przypadki nadużyć seksualnych wobec nieletnich (około 4\% wszystkich duchownych), a prawomocnymi wyrokami skazano około 100 osób (o,o9\% wszystkich duchownych) ${ }^{20}$.

Drugi w kolejności dokument został przygotowany w 2013 roku w Australii przez Królewską Komisję ds. Odpowiedzi Instytucji na Wykorzystywanie Seksualne Dzieci. Badaniami objęto instytucje kościelne od 1950 do

${ }^{18}$ Kryteria diagnostyczne tej parafilii zawarte są w klasyfikacjach: American Psychiatric Association, Diagnostic and Statistical Manual of Mental Disorders. (5th Edition), Washington 2013, (DSM 302.2); World Health Organization, International Statistical Classification of Diseases and Related Health Problems (ICD-11), Geneva 2018, (F65.4).

19 Seksualna preferencja dorosłych do kontaktów $\mathrm{z}$ osobami w późnym okresie dojrzewania (około 15-18 lat). Określenie choć nie występuje w klasyfikacjach zaburzeń psychicznych ICD-11 i DSM-5, to wskazywane jest w literaturze przedmiotu jako parafilia z grupy niespecyficznych. Należy także dodać, że współżycie seksualne z osobą powyżej 15 roku życia, a przed uzyskaniem pełnoletniości, w prawodawstwach wielu państw nie jest karane. Jest to zdecydowanie inna sytuacja niż normy kanoniczne, które takiej granicy nie uznają.

${ }^{20}$ Pełna wersja raportu: United States Conference of Catholic Bishops, The Causes and Context of Sexual Abuse of Minors by Catholic Priests in the United States, 1950-2010. A Report Presented to the United States Conference of Catholic Bishops by the John Jay College Research Team, Washington 2011, http://www.usccb.org/issues-andaction/child-and-youth-protection/upload/The-Causesand-Context-of-Sexual-Abuse-of-Minors-by-Catholic-Priests-in-the-United-States-1950-2010. pdf (10.10.2018); zob. G. Górny, Afera pedofilska jest tak naprawdę aferq homoseksualna, https:// wpolityce.pl/polityka/409953-afera-pedofilska-jest-tak-naprawde-afera-homoseksualna (6.10.2018); S. Duda, Nie tylko Ameryka..., „Przegląd Powszechny” (2010) nr 9, s. 4-5. 
2015 roku (okres 65 lat). Raport ujawnia, że 7\% osób duchownych dopuściło się przestępstwa wobec nieletnich. Dokonano tego na podstawie zgłoszeń 4444 osób, które twierdziły, że były molestowane. Około 90\% sprawców czynów kryminalnych wśród księży stanowili homoseksualiści ${ }^{21}$.

Trzeci wspomniany raport został zlecony przez Niemiecki Episkopat trzem ośrodkom uniwersyteckim. Przeanalizowano wszystkie przypadki nadużyć seksualnych osób duchownych wobec nieletnich w Niemczech (27 diecezji) na przestrzeni 70 lat (od 1946 do 2014 roku). Raport został opracowany po analizie ponad 38 tys. akt personalnych i dokumentów. Także w tym kraju ofiary pedofilii to przede wszystkim nieletni chłopcy, a sprawcami w większości byli księża o orientacji homoseksualnej. Grupa księży, która dopuściła się czynów molestowania seksualnego to łącznie 1670 osób (4,3\% wszystkich duchownych). Łącznie odnotowano 3677 przypadków molestowania. Połowa ofiar w chwili dokonywania na nich przestępstwa miała maksymalnie 13 lat $^{22}$.

Należy wspomnieć tutaj także o raporcie, który został przygotowany w 2018 roku w Stanach Zjednoczonych w stanie Pensylwania. Charakter tego dokumentu jest jednak nieco inny niż tych trzech wcześniej przywołanych. Dwuletnie badania zaowocowały 9oo-stronicowym dokumentem. Według tych danych $74 \%$ sprawców czynów kryminalnych wśród duchownych dotyczyło homoseksualistów, a ich ofiarami byli przede wszystkim nieletni chłopcy. Wielka Ława Przysięgłych stanu Pensylwania przygotowała dokument, w którym stwierdza, że w ośmiu diecezjach tego stanu w ciągu 70 lat grupa 301 księży dopuściła się ponad tysiąc przestępstw seksualnych. Wspomniane nadużycia miały miejsce zasadniczo do roku $2000^{23}$.

${ }^{21}$ Pełna wersja raportu: Royal Commission into Institutional Responses to Child Sexual Abuse, The Final Report, https://www.childabuseroyalcommission.gov.au/ (12.10.2018); zob. G. Górny, Afera pedofilska..., dz. cyt.; G. Górny, Mówienie prawdy o skandalu homoseksualno-pedofilskim jako „mowa nienawiści” podlegająca cenzurze, https://wpolityce.pl/kosciol/415347-przywolaniefaktow-moze-byc-ocenione-jako-mowa-nienawisci (6.10.2018).

${ }^{22}$ Pełna wersja raportu: Deutschen Bischofskonferenz, Sexueller Missbrauch an Minderjährigen durch katholische Priester, Diakone und männliche Ordensangehörige im Bereich der Deutschen Bischofskonferenz, Mannheim, Heidelberg, Gießen, 24.09.2018, https://www.dbk.de/fileadmin/ redaktion/diverse_downloads/dossiers_2018/MHG-Studie-gesamt.pdf(15.10.2018); zob. Vatican News, Niemcy: reakcje po raporcie o nadużyciach, https:/www.vaticannews.va/pl/kosciol/news/2018-o9/ niemcy-biskupi-raport-naduzycia-duchowni-wstyd.html (10.10.2018); G. Górny, Kolejne badania uniwersyteckie potwierdzaja zwiazek między homoseksualizmem a pedofilia, https://wpolityce.pl/ kosciol/412418-zwiazek-miedzy-homoseksualizmem-a-pedofilia (6.10.2018).

${ }^{23}$ Pełna wersja raportu: Pennsylvania Grand Jury, 4oth Statewide Investigating Grand Jury Report 1 Interim - Redacted, Pennsylvania 2018, https://assets.documentcloud.org/documents/4756976/ 
Dotychczasowe naukowe i prawne analizy oraz merytoryczne raporty pozwalają wyciągnąć przynajmniej kilka wniosków.

Po pierwsze, zdecydowana większość dokonywanych przestępstw seksualnych przez duchownych miała związek $\mathrm{z}$ ich fascynacją, tendencjami oraz aktywnością homoseksualną ${ }^{24}$.

Po drugie, ofiarami osób duchownych były przede wszystkim osoby w wieku dorastania. Nadużycia seksualne dotyczyły przede wszystkim młodocianych płci męskiej. Inne badania naukowe dotyczące wykorzystywania seksualnego nieletnich przez duchownych w Ameryce potwierdzają informacje zawarte we wspomnianych raportach, że większość badanych przypadków dotyczyła jednak efebofilii, a nie pedofilii ${ }^{25}$. To rozróżnienie ważne jest z punktu widzenia prawodawstwa wielu państw, ale nie Kościoła. Stanowisko Kościoła bowiem nie rozróżnia tych sytuacji i jest zdecydowanie bardziej restrykcyjne niż jakiekolwiek prawodawstwo świeckie.

Po trzecie, raporty pokazują jednoznacznie, że przypadki nadużyć seksualnych wśród duchownych wobec nieletnich swoje największe nasilenie miały miejsce w latach 1960-1980. Początek tych skandalicznych zachowań osób duchownych zbiega się jednoznacznie z początkiem tzw. rewolucji seksualnej w świecie. To wtedy ujawniła się także ogromna wewnątrzkościelna kontestacja encykliki Humanae vitae i skrajnie lekceważące traktowanie papieża Pawła vi i jego roli w Kościele. To sytuacja w Kościele, gdy w owczarni „panuje zamęt”, a owce „pokazują zęby” i "gryzą swojego pasterza” ${ }^{26}$.

Czwartą istotną informacją jest realna skala przestępstw osób duchownych na podstawie prawomocnych wyroków skazujących. Biorąc pod uwagę liczbę duchowieństwa w analizowanym okresie czasowym oraz liczbę skazanych

READ-Pennsylvania-priest-abuse-grand-jury-report.pdf(11.10.2018); zob. Vatican News, Pensylwania: raport o nadużyciach seksualnych $w$ Kościele, https://www.vaticannews.va/pl/kosciol/news/2018-o8/ usa-pensylwania-raport-naduzycia-seksualne-skrucha-smutek-wstyd.html (10.10.2018); G. Górny, Afera pedofilska..., dz. cyt.

${ }^{24}$ Związek homoseksualizmu z nadużyciami seksualnymi wśród duchownych potwierdza raport przygotowany przez organizację z Luizjany: Ruth Institute, D. Paull Sullins, Report: Clergy Sex Abuse, http://www.ruthinstitute.org/(6.11.2018).

${ }_{25}$ Por. P. Cimbolic, P. Cartor, Looking at Ephebophilia through the Lens of Cleric Sexual Abuse, "Sexual Addiction \& Compulsivity: The Journal of Treatment \& Prevention” 13 (2006) no. 4, s. 347-359; P. Cartor, P. Cimbolic, J. Tallon, Differentiating Pedophilia from Ephebophilia in Cleric Offenders, „Sexual Addiction \& Compulsivity: The Journal of Treatment \& Prevention” 14 (2008) no. 4, s. 311-319.

${ }^{26}$ Por. R. Skrzypczak, Chrześcijanin na rozdrożu, dz. cyt., s. 114-137. 
a także - co jest bardzo istotne - całkowitą liczbę przestępstw seksualnych wobec nieletnich w tych trzech państwach, należy mówić o wartościach typu promile, a nie procenty.

Przemyślany i zorganizowany przemysł pogardy i zohydzania Kościoła znajduje podatny grunt szczególnie tam, gdzie wcześniej wyeliminowana jest „posługa myślenia”, czyli służba prawdzie realizowana wraz z różnymi cnotami moralnymi - wśród ludzi z mentalnością niewolnika.

\section{Strategia przeciwdziałania ze strony Kościoła}

Choćby jeden czyn osoby duchownej związany z nadużyciem seksualnym wobec osoby nieletniej w jakimkolwiek obszarze tej sfery jest sprzeniewierzeniem się wobec fundamentalnej posługi - „posługi myślenia” oraz własnego powołania do kapłaństwa. Ale także każda manipulacja i propaganda medialna w tej kwestii dotycząca generalizowania pojedynczych zachowań osób duchownych i czynienie z tych zachowań problemu całego Kościoła jest również jednoznacznym zaprzeczeniem chrześcijańskiej „posługi myślenia”. W obu sytuacjach prawda i dobro są bowiem pomijane w życiu osobistym i społecznym. Kościół bardzo potrzebuje oczyszczenia w analizowanym obszarze, ale z całą pewnością nie może go wyznaczać antyklerykalny wrzask. Ogólną wartością merytorycznych raportów, które ukazały się dotychczas w świecie i dotyczyły analizy nadużyć seksualnych osób duchownych wobec nieletnich, jest ukazanie prawdy.

Kościół musi wychodzić z tej sytuacji, tylko i wyłącznie łącząc prawdę z realizowaniem cnót moralnych: konieczne jest bezwzględnie krytyczne stanowisko wobec przestępców seksualnych i bezwzględnie pozytywne i empatyczne stanowisko wobec ofiar tych przestępstw. Postawa realizowania prawdy wraz z cnotą moralną i bez niej jest dobrze znana z historii Kościoła. Można przywołać choćby postawę dwóch apostołów: Piotra i Judasza. Obaj uznali prawdę o swoim życiu. Obaj uświadomili sobie, że zgrzeszyli, obaj wyparli się Chrystusa. Piotr tę prawdę połączył ze skruchą i żalem oraz przyjęciem przebaczenia, natomiast Judasz nie był w stanie podjąć takiej postawy. Konsekwencje w dalszym życiu dla obu apostołów były zdecydowanie różne. „Posługa myślenia” musi być realizowana wraz z różnymi cnotami moralnymi!

Wchodzenie w dialog z wrogami Kościoła posiadającymi ogromne możliwości medialnej manipulacji i propagandy skazane jest zawsze na porażkę. Wrogom Kościoła nigdy nie zależało i nie zależy na reformowaniu Kościoła, tylko na jego zniszczeniu. Do tego celu wykorzystywana jest bezpardonowo machina 
wszelkich działań antykościelnych. Wrogów Kościoła nie tylko nie interesuje prawda, ale tym bardziej nie interesują ich cnoty moralne. W przypadku nadużyć seksualnych samo bazowanie na prawdzie, czyli jedynie na skali problemu, nie wystarczy! Tym bardziej nie wystarczy bazowanie na tzw. półprawdach.

Uwarunkowania pedofilii mają swoje źródło zwykle w sytuacjach z wczesnego dzieciństwa lub z lat młodości potencjalnych przestępców. Kościół nie wzywa do wykorzystywania seksualnego nieletnich, nie przygotowuje do takich zachowań w seminariach duchownych, nie broni ani nie afirmuje takich zachowań, więc to konkretni sprawcy powinni odpowiadać za swoje czyny, a nie cały Kościół. Jeśli pojawiają się sytuacje świadomego ukrywania nadużyć seksualnych wobec nieletnich, to te zachowania powinny być traktowane jako współuczestnictwo. Ale ciągle jest to odpowiedzialność osobista, a nie zbiorowa. Posługa myślenia jako służba prawdzie musi być związana z cnotą odpowiedzialności za własne czyny!

Aktualna i obowiązująca w całym Kościele jest Instrukcja dotycząca kryteriów rozeznawania powołania $w$ stosunku do osób z tendencjami homoseksualnymi w kontekście przyjmowania ich do seminariów i dopuszczania do święceń, opracowana przez Kongregację Edukacji Katolickiej i ogłoszona 29 listopada 2005 roku. Kardynał Joseph Ratzinger jednoznacznie stwierdza w tym dokumencie, że „osób, które praktykują homoseksualizm, wykazują głęboko zakorzenione tendencje homoseksualne lub wspierają tak zwaną «kulturę gejowską»" ${ }^{\text {nie }}$ nie powinno się przyjmować do seminariów i dopuszczać do święceń kapłańskich. To stanowisko jest owocem bardzo wnikliwej analizy najsłynniejszego z raportów, czyli tzw. John Jay Report. Mając na uwadze fakt, że osoby homoseksualne stanowią jedynie do $2 \%$ całej populacji, można wyciągnąć jednoznaczny wniosek, że wśród księży, którzy dopuścili się nadużyć seksualnych wobec nieletnich, istnieje wręcz gigantyczna nadreprezentacja tych osób. Z przykrością należy stwierdzić, że wśród duchownych na zachodzie Europy - w tym także wśród biskupów - istnieją osoby, które oficjalnie wspierają „kulturę gejowską". Ta sytuacja wymaga zdecydowanego uzdrowienia, aby skutecznie walczyć także z nadużyciami seksualnymi wobec nieletnich przez duchownych. Poradzenie sobie z wpływem gejowskim w Kościele jest fundamentalnym krokiem w wychodzeniu z tzw. kryzysu pedofilskiego. Chrześcijańska „posługa myślenia” i „kultura gejowska” wykluczają się radykalnie!

${ }^{27}$ Kongregacja Edukacji Katolickiej, Instrukcja dotycząca kryteriów rozeznawania powołania $w$ stosunku do osób z tendencjami homoseksualnymi w kontekście przyjmowania ich do seminariów i dopuszczania do święceń, Rzym 2005. 
Należy także wspomnieć, że Kościół na przestrzeni lat wypracował wiele innych ważnych dokumentów, których ścisłe przestrzeganie pozwoliłoby ustrzec się tego globalnego kryzysu wywołanego jednak przez stosunkowo nieliczną grupę osób duchownych. Problem nadużyć seksualnych kapłanów wobec nieletnich podjął Jan Paweł II, później Benedykt XVI i obecnie podejmuje papież Franciszek. Owocem tych działań jest wręcz całkowity brak tych przestępstw w ostatnich kilkunastu latach np. w Niemczech i Stanach Zjednoczonych. „Tam gdzie przebywali uczniowie, gdy drzwi były zamknięte z obawy przed Żydami, przyszedł Jezus, stanął pośrodku i rzekł do nich: «Pokój wam!»” (J 20, 19). W czasach współczesnych można odnieść wrażenie, że drzwi są dalej mocno zamknięte, a obawa wynika przede wszystkim $\mathrm{z}$ tego, co napiszą antykatolickie media. W kilku ostatnich latach zauważa się w Kościele postawę nieustannego wręcz przepraszania. U osób należących do wspólnoty Kościoła rodzą się wówczas pytania i wątpliwości dotyczące skali problemu i powagi używanego słowa, tworzy się u wiernych fałszywe wrażenie powszechności tych patologicznych zachowań. Czy przepraszanie biskupów w imieniu całej lokalnej wspólnoty ma większe znaczenie niż już kilkukrotne przeproszenie przez ostatnich papieży? Nie można pominąć też faktu jawnej dewaluacji tego słowa w życiu społecznym. Słowa przeprosin, jeśli mają odnieść pozytywny skutek, powinny być skierować do konkretnych ofiar w indywidualnym spotkaniu, przy czym należy pamiętać, że ze strony instytucji reprezentujących ofiary nadużyć seksualnych słychać coraz głośniejsze wołanie, iż „ofiary nie chcą kolejnego przepraszania”. „Posługa myślenia” musi być więc powiązana $\mathrm{z}$ dobrem osobistym oraz z dobrem całej wspólnoty.

I sprawa wręcz najistotniejsza: postawa Kościoła wobec ofiar wykorzystania seksualnego przez duchownych. Jeśli problem ma być rozwiązany z całą stanowczością i zdecydowaniem, a jednocześnie ze sprawiedliwością i miłością, konieczne jest spotkanie z tymi osobami niejako twarzą w twarz. Oczywiście bezpośredni sprawcy mogą już być poza kapłaństwem, a nawet Kościołem, mimo to spotkanie z przedstawicielem Kościoła jest konieczne, jeśli tylko ofiara przestępstwa wyraża taką gotowość. Człowiek poniżony i upokorzony, po traumie wykorzystania seksualnego czuje się zbrudzony, uprzedmiotowiony, często czuje się niesłusznie winny. Ból i poczucie zdrady kojarzonej z Bogiem, którego reprezentował kapłan, wymaga spotkania pełnego autentycznej miłości. Osoby pokrzywdzone muszą zgłosić problem zarówno Kościołowi, jak i organom ścigania. Tylko tak można przerwać aktualny, przestępczy proceder oraz rozliczyć się z przeszłością. „Zgłaszanie się ofiar molestowania seksualnego przez księży nie powinno być traktowane jako ciężar, ale wręcz 
jako dar. To dzięki ich świadectwu, które wymaga od nich nieraz heroicznej postawy, Kościół może skutecznie walczyć z przestępstwem wykorzystywania seksualnego małoletnich w szeregach kapłańskich" ${ }^{28}$.

Osoby skrzywdzone potrzebują „duchowego człowieka” i „ludzkiego duchownego”, który potrafi wczuć się w problem ofiary bez jakiegokolwiek wartościowania (empatia). Potrzebna jest postawa szacunku i troski (akceptacja). I wreszcie konieczna jest zgodność tego, co słychać w Kościele, („zero tolerancji dla pedofilii w Kościele”) z gotowością pomocy (autentyczność). Tylko w klimacie takiej rozmowy duszpasterskiej możliwe jest rozwiązanie problemu. Tego wymaga także chrześcijańska „posługa myślenia”. Potrzebne są zdecydowane działania, w których ofiary przestępstw doświadczają, że Kościół jest po ich stronie. Jakiekolwiek unikanie ich ze strony Kościoła może być odbierane jako ukrywanie sprawców lub ich usprawiedliwianie i relatywizowanie przestępczego zachowania ${ }^{29}$.

Pomocna w rozwiązaniu każdego kryzysu w Kościele może być wypowiedź papieża Benedykta XVI z 2017 roku. Emerytowany papież wypowiedział znamienne słowa przy pogrzebie kard. Meisnera: „[...] żyć głębokim przekonaniem, że Pan nie opuszcza swojego Kościoła, nawet kiedy łódź nabrała tak wiele wody, że prawie już tonie" ${ }^{\prime \prime}$. Choć słowa padły w innej sytuacji i były wyrazem szczególnego uznania dla zmarłego kardynała, to są one bardzo aktualne także w kontekście aktualnego kryzysu dotykającego cały Kościół. $\mathrm{Z}$ całą pewnością słowa te bardzo mocno korespondują $\mathrm{z}$ inną wypowiedzią kard. Ratzingera, przywołującego swego poprzednika na Stolicy Piotrowej: „Kościół dzisiejszy nie potrzebuje nowych reformatorów. Kościół potrzebuje nowych świętych" ${ }^{\prime 1}$.

Rozwiązanie każdego kryzysu w Kościele znajdziemy również w ciągle aktualnych słowach Jana Pawła II. Otóż w rok po wypowiedzeniu znamiennych słów dotyczących „posługi myślenia” zwrócił się do polskich biskupów, aby zachęcali kapłanów do stałej formacji i w ten sposób „stawali się coraz pełniej i dojrzalej ludźmi wiary i świętości [...]. «Świat dzisiejszy woła o kapłanów

${ }^{28}$ J. Augustyn, Sytuacja Kościoła jest krytyczna, http://www.fronda.pl/a/ks-jozef-augustyn-sjsytuacja-kosciola-jest-krytyczna,115831.html (18.10.2018).

29 Por. J. Augustyn, Sytuacja Kościoła jest krytyczna, dz. cyt.

${ }^{30}$ Benedykt XvI, Grußwort des emeritierten Papstes Benedikt XVI in der Beisetzungsfeier von Kardinal Joachim Meisner, am 15.07.2017, https://www.domradio.de/sites/default/files/pdf/170715_ papst_em_benedikt_gr_requiem_meisner.pdf (18.10.2018).

${ }^{31}$ J. Ratzinger, V. Messori, Raport o stanie wiary. Z ks. Kardynałem Josephem Ratzingerem rozmawia Vittorio Messori, tłum. Z. Orszyn i in., Kraków-Warszawa 1986, s. 35. 
świętych! Tylko kapłan święty może stać się w dzisiejszym, coraz bardziej zsekularyzowanym świecie przejrzystym świadkiem Chrystusa i Jego Ewangelii. Tylko w ten sposób kapłan może stawać się dla ludzi przewodnikiem i nauczycielem na drodze do świętości, a ludzie - zwłaszcza młodzi - na takiego przewodnika czekają. Kapłan może być przewodnikiem i nauczycielem o tyle, o ile stanie się autentycznym świadkiem»"32.

Powyższe stanowisko wzywające do świętości kapłańskiego życia to „posługa myślenia” w najczystszej formie. Realizacja tej posługi to pewność, że „bramy piekielne go nie przemogą" $(\mathrm{J} 16,18)$, to pewność Ecclesia vincens et pulchra!

\section{ABSTRAKT}

Jednym z najważniejszych zadań chrześcijanina jest „posługa myślenia”, o której uczył Jan Paweł II. Zwłaszcza w obliczu antychrześcijańskiej propagandy, która narzuca wizję Kościoła odrażającego, szpetnego, brzydkiego - Ecclesia turpis. Pytanie problemowe brzmi: jak ma reagować chrześcijanin wobec tej propagandy, wykorzystując posługę myślenia?

Punktem wyjścia w artykule jest analiza papieskiego pojęcia „posługa myślenia” i zagrożenia wynikającego z odrzucenia tej posługi, tj. kształtowania mentalności niewolnika. Kolejny etap to rozpatrzenie współczesnych mechanizmów zohydzania Kościoła przejawiających się w przypisywaniu mu czynów kryminalnych na ogromną skalę oraz wywoływaniu u odbiorców negatywnych emocji. Na końcu przedstawiono stanowisko wobec powyższego procesu, ze szczególnym uwzględnieniem problemu wykorzystywania seksualnego nieletnich przez duchownych. Artykuł ma charakter teologiczno-psychologiczny.

\section{SŁOWA KLUCZOWE}

Kościół, „posługa myślenia”, „mentalność niewolnika”, wykorzystywanie seksualne nieletnich, pedofilia, pomoc osobom wykorzystanym seksualnie

${ }^{32}$ Jan Paweł II, Odnowa człowieka i społeczeństwa dokonuje się za sprawa odnowy sumień, dz. cyt., s. 47. 


\section{Abstract}

\section{The Ministry of Thinking and the Contemporary Approach} of Ecclesia turpis. Theological and Psychological Reflection

The ministry of thinking taught by Pope John Paul II is one of the most important task of a Christian. On the other hand, this is an anti-Christian propaganda which creates a vision of the Church as repugnant, unsightly and ugly - Ecclesia turpis. The problem question is: how a Christian should react to the propaganda process using the ministry of thinking?

The analysis of the concept of Pope John Paul II's "ministry of thinking", as well as the dangers resulting from the rejection of this ministry, namely shaping the mentality of a slave, is a starting point in the article. In the next stage the author elaborates on the contemporary mechanisms used in order to disparage the Church by attributing to it the criminal offences on a large scale and evoking negative emotions in the minds of the recipients. The final reflection presents the proposition of the Approach towards the above-mentioned process, with particular reference to the problem of the sexual abuse of minors by the clergy. The article is of theological and psychological nature.

\section{KeYWORDS}

Church, "the ministry of thinking”, "mentality of a slave”, sexual abuse of minors, paedophilia, help for sexually abused people

\section{BIBLIOGRAFIA}

American Psychiatric Association, Diagnostic and Statistical Manual of Mental Disorders. (5th Edition), Washington 2013.

Augustyn J., Sytuacja Kościoła jest krytyczna, http://www.fronda.pl/a/ks-jozef-augustyn-sj-sytuacja-kosciola-jest-krytyczna,115831.html (18.10.2018).

Benedykt XVI, Grußwort des emeritierten Papstes Benedikt XVI in der Beisetzungsfeier von Kardinal Joachim Meisner, am 15.07.2017, https://www.domradio.de/sites/default/files/pdf/170715_papst_em_benedikt_gr_requiem_meisner.pdf (18.10.2018).

Bukalski S., Manipulacyjny język w grupach kultowych, w: Język przekazu religijnego, red. D. Krok, S. Pawiński, Opole 2006, s. 65-79.

Cartor P., Cimbolic P., Tallon J., Differentiating Pedophilia from Ephebophilia in Cleric Offenders, „Sexual Addiction \& Compulsivity: The Journal of Treatment \& Prevention" 14 (2008) no. 4, s. 311-319.

Cialdini R., Wywieranie wpływu na ludzi. Teoria i praktyka, przeł. B. Wojciszke, Gdańsk 1996. 
Cimbolic P., Cartor P., Looking at Ephebophilia through the Lens of Cleric Sexual Abuse, „Sexual Addiction \& Compulsivity: The Journal of Treatment \& Prevention” 13 (2006) no. 4, s. 347-359.

Crocker J., Piętno, stygmat, w: A. Manstead, M. Hewstone, Encyklopedia Blackwella. Psychologia społeczna, red. naukowa J. Czapiński, tłum. zbior., Warszawa 1996, s. 348-350.

Deutschen Bischofskonferenz, Sexueller Missbrauch an Minderjährigen durch katholische Priester, Diakone und männliche Ordensangehörige im Bereich der Deutschen Bischofskonferenz, Mannheim, Heidelberg, Gießen, 24.09.2018, https://www.dbk. de/fileadmin/redaktion/diverse_downloads/dossiers_2018/MHG-Studie-gesamt. pdf (15.10.2018).

Duda S., Nie tylko Ameryka..., „Przegląd Powszechny” 2010 nr 9, s. 121-130.

Emler N., Etykietowanie, w: A. Manstead, M. Hewstone, Encyklopedia Blackwella. Psychologia społeczna, red. naukowa J. Czapiński, tłum. zbior., Warszawa 1996, s. 104. Górny G., Afera pedofilska jest tak naprawdę afera homoseksualna, https://wpolityce.pl/polityka/409953-afera-pedofilska-jest-tak-naprawde-afera-homoseksualna (6.10.2018).

Górny G., Mówienie prawdy o skandalu homoseksualnopedofilskim jako „mowa nienawiści" podlegająca cenzurze, https://wpolityce.pl/kosciol/415347-przywolanie-faktow-moze-byc-ocenione-jako-mowa-nienawisci (6.10.2018).

Górny G., Kolejne badania uniwersyteckie potwierdzaja zwiazek między homoseksualizmem a pedofilia, https://wpolityce.pl/kosciol/412418-zwiazek-miedzy-homoseksualizmem-a-pedofilia (6.10.2018).

Gursztyn P., Korek, worek i rozporek, http://wiadomosci.dziennik.pl/opinie/artykuly/14816o,korek-worek-i-rozporek.html (2.10.2018).

Ivanowitz A., Korek, worek i rozporek, http://www.pospoliteruszenie.org (2.10.2018). Jan Paweł II, Przemówienie wygłoszone z okazji sześćsetlecia Wydziału Teologicznego Uniwersytetu Jagiellońskiego, Kraków 8 czerwca 1997, https://ekai.pl/dokumenty/przemowienie-wygloszone-z-okazji-szescsetlecia-wydzialu-teologicznego-uj/(15.09.2018). Jan Paweł II, Odnowa człowieka i społeczeństwa dokonuje się za sprawa odnowy sumień. Przemówienie Ojca Świętego do III grupy biskupów polskich z wizytą ad limina, Rzym 14.02.1998, „L'Osservatore Romano” (wyd. pol.) 1998 nr 3, s. 43-47.

Kamińska-Feldman M., Wokół problemu dehumanizacji innych: próba uchwycenia zjawiska stygmatyzacji, w: Poza egocentryczna perspektywa widzenia siebie iświata, red. M. Jarymowicz, Warszawa 1994, s. 63-86.

Kongregacja Edukacji Katolickiej, Instrukcja dotyczaca kryteriów rozeznawania powołania $w$ stosunku do osób z tendencjami homoseksualnymi w kontekście przyjmowania ich do seminariów i dopuszczania do święceń, Rzym 2005. 
Kozielecki J., Koncepcje psychologiczne człowieka, Warszawa 1996.

Kucharczyk G., Antykatolickie kampanie, „Nasz Dziennik” 22-23.09.2018, s. 8.

Maslow A. H., Motywacja i osobowość, przeł. P. Sawicka, Warszawa 1990.

Mosse G., Sessaualitá e nazionalismo. Mentalitá borghese e rispettabilitá, Roma 1996. Müller G., Żaden kraj nie ma prawa pouczać Polski na temat demokracji, https://www. gosc.pl/doc/5099501.Kard-Mueller-Zaden-kraj-nie-ma-prawa-pouczac-Polski-natemat (18.10.2018).

Pennsylvania Grand Jury, 4oth Statewide Investigating Grand Jury Report 1 Interim - Redacted, Pennsylvania 2018, https://assets.documentcloud.org/documents/4756976/ READ-Pennsylvania-priest-abuse-grand-jury-report.pdf (11.10.2018).

Radio Watykańskie, Doroczny raport usa o wolności religijnej w świecie, http://pl.radiovaticana.va/news/2017/08/17/doroczny_raport_usa_o_wolno\%C5\%9Bci_religijnej_w_\%C5\%9Bwiecie/1331272 (5.08.2018).

Ratzinger J., Messori V., Raport o stanie wiary. Z ks. Kardynałem Josephem Ratzingerem rozmawia Vittorio Messori, tłum. Z. Orszyn i in., Kraków-Warszawa 1986.

Royal Commission into Institutional Responses to Child Sexual Abuse, The Final Report, https://www.childabuseroyalcommission.gov.au/(12.10.2018).

Salij J., Dwa opisy mentalności niewolniczej, „Arcana” 1997 nr 15, s. 142-146.

Salij J., Ośrodek Myśli Politycznej, Mentalność niewolnicza jako problem narodowy, http://www.omp.org.pl/artykul.php?artykul=167 (5.10.2018).

Schopenhauer A., Erystyka, czyli sztuka prowadzenia sporów, tłum. Ł. Konorska, B. Konorski, Warszawa 2012.

Skrzypczak R., Chrześcijanin na rozdrożu, Kraków 2011.

Starowieyski M., Pierwsi świadkowie. Pisma Ojców Apostolskich, Kraków 2010.

United States Conference of Catholic Bishops, The Causes and Context of Sexual Abuse of Minors by Catholic Priests in the United States, 1950-2010. A Report Presented to the United States Conference of Catholic Bishops by the John Jay College Research Team, Washington 2011, http://www.usccb.org/issues-and-action/child-and-youth-protection/upload/The-Causes-and-Context-of-Sexual-Abuse-of-Minors-by-Catholic-Priests-in-the-United-States-1950-2010.pdf (10.102018).

Witkowski T., Psychomanipulacje, Wrocław 2000.

Wojtyła K., Miłość i odpowiedzialność, Lublin 2001.

Wolicka E., Posługa myślenia - Jana Pawła II idea uniwersytetu, w: Fenomen uniwersytetu, red. A. Grzegorczyk, J. Sójka, Poznań 2008, s. 75-82.

World Health Organization, International Statistical Classification of Diseases and Related Health Problems (ICD-11), Geneva 2018.

Żukowska-Gardzińska D., Kulturowe wyposażenie osoby, „Fides et Ratio” 24 (2015) nr 4, s. 64-71. 
Vatican News, Pensylwania: raport o nadużyciach seksualnych $w$ Kościele, https://www. vaticannews.va/pl/kosciol/news/2018-o8/usa-pensylwania-raport-naduzycia-seksualne-skrucha-smutek-wstyd.html (10.10.2018).

Vatican News, Niemcy: reakcje po raporcie o nadużciach, https://www.vaticannews.va/ $\mathrm{pl} /$ kosciol/news/2018-09/niemcy-biskupi-raport-naduzycia-duchowni-wstyd.html (10.10.2018). 